\title{
Teaching English Through Spanish: A Secondary School EFL Teachers's Language Choices in the Foreign Language Classroom
}

\author{
Marisa Morata and Yvette Coyle \\ University of Murcia, Spain
}

Received: 27 March $2011 /$ Accepted 5 June 2011

ISSN: $1697-7467$

\begin{abstract}
The present study examines the language used by a Spanish secondary school teacher of English. Taking as a basic premise that exposure to the foreign language is conducive to language learning, transcripts of classroom discourse were analysed to identify the pedagogical functions present in the teacher's speech and the language used to express them. The results show an overwhelming reliance by the teacher on the students' first language for all of the most frequently occurring functions. Instances of target language use and code switching were also identified. The implications of these results are discussed in the light of previous studies and suggestions are made for increasing target language use in foreign language classrooms.
\end{abstract}

Keywords: L1, target language use, teacher discourse, pedagogical functions

La enseñanza del inglés a través del español: las elecciones lingüísticas del profesorado de idioma en el aula de lengua extranjera

RESUMEN: Este estudio se centra en el uso del lenguaje por parte de una profesora de inglés de secundaria. Partiendo de la idea de que la exposición a un idioma extranjera facilita el aprendizaje del mismo, se analizaron transcripciones del discurso de aula con el fin de identificar las funciones pedagógicas en el habla de la profesora y el idioma elegido para expresarlas. Los resultados muestran un uso casi exclusivo de la lengua materna para la mayoría de las funciones pedagógicas. También se identificaron muestras del uso de la lengua extranjera, así como del cambio de código. Los resultados se presentan a la luz de investigaciones previas y se hacen sugerencias para incrementar el uso de inglés en el aula.

Palabras clave: L1, lengua extranjera, discurso del profesor, funciones pedagógicas

\section{INTRODUCTION}

Current methodological proposals for language teaching in Spain are based on the principles of the communicative approach. According to the Curriculum for Secondary Education, students of foreign languages should aim to develop sufficient communicative competence to enable them to understand information in different communicative situations and to interact autonomously with a reasonable command of the phonetic, lexical, structural and functional elements of the second language. A basic premise of the Curriculum is that 
for students to develop competence in a foreign language (FL), the role of teachers as models of the language is crucial. Exposure to the foreign language is seen to play an important role in maximizing students' language learning potential.

This idea is not new. Theories of second language acquisition (SLA) have long reinforced the importance of the role of the second language (L2 ) in language learning. While Krashen's comprehensible input hypothesis (1985) claimed that language is acquired only when learners understand input slightly beyond their current level of competence, Long's interaction theory (1985) posed that a second language is acquired through negotiated interaction and emphasized the importance of the speech modifications made by interlocutors during conversation. Speech adjustments such as paraphrase, repetition, clarification requests, here-and-now topics, confirmation checks, comprehension checks, expansions or short responses, are also thought to be important for foreign language teachers who take on the role of native speakers when providing learners with rich and meaningful comprehensible input to foster their language development (Ellis, 1994). As a counterpoint to these receptive theories, Swain's (1985) comprehensible output theory suggested learners need opportunities to produce the L2 and to receive feedback, both of which are important in enabling them to detect any mismatch between their own production and the correct L2 forms, leading ultimately, it is claimed, to the restructuring of their knowledge of the language. The implication of these theories is that L2 exposure is crucial in SLA and that the opportunity to produce output and engage in meaning negotiation are necessary for the knowledge of the second language to develop and improve.

\section{RECENT RESEARCH ON TEACHERS'S LANGUAGE CHOICES IN THE CLASSROOM}

Although several key studies have been carried out on the issue of teachers' language choices in the FL or L2 classroom, as yet, the literature on this topic has not reached a definitive conclusion from which general pedagogical implications may be extracted. In a foreign language learning context, where there is little opportunity beyond the classroom to receive input in the L2, the quantity and quality of input the learners are exposed to are thought to be necessary, if insufficient, conditions for language learning (Duff \& Polio, 1990). Since the FL teacher is often the only source of available L2 input, it is therefore assumed that use of the L1 and code switching between both languages should be minimized in the classroom. Instead, teachers are encouraged to use the L2 as much as possible to create optimum conditions for language learning.

In an early study carried out by Duff and Polio (1990), thirteen native speaker (NS) teachers of different foreign languages at the University of California were observed and their language use coded. The results of the study showed a great deal of variability in the teachers' use of the FL in their classes, which ranged from ten to 100 percent, although six of the teachers were found to use the FL ninety percent or more of the time. In interviews carried out with the teachers, they expressed diverging opinions on why they used the FL more or less frequently. Factors mentioned in favour of FL use included previous training, personal learning experiences or theoretical convictions, while those 
who expressed reservations on using the FL complained about time limitations, their students' lack of understanding or the fact that they were following departmental policy.

In a later study, Polio \& Duff (1994) analysed six out of the thirteen university FL classrooms included in the previous study, in order to examine how and when the teachers used the L1 and the FL. Eight common uses of the L1 (English) were identified in the discourse of the six teachers. These included classroom administrative vocabulary, grammar instruction, classroom management, showing empathy/solidarity, unknown vocabulary/translation, practicing English (students helping teachers improve their nonnative English), lack of comprehension by the students, and an interactive effect involving students' use of English. In interviews carried out with the teachers, they revealed a lack of awareness of what the L1 was used for. Their answers showed that they all were in favour of using the FL as much as possible, although they complained that they had too much material to cover which caused time restrictions in class. Underlying these early studies then is the idea that FL use should be maximized in the classroom.

Other researchers, however, have taken a different view on the issue. Antón and Di Camilla (1999) are among those authors who consider the L1 as a powerful tool for learning. In their paper, they study the use of L1 (English) in collaborative interaction in a L2 (Spanish) classroom where students externalized their inner speech during a writing task. According to these authors,

the use of L1 is beneficial for language learning, since it acts as a critical psychological tool that enables learners to construct effective collaborative dialogue in the completion of meaning-based language tasks by performing three important functions: construction of scaffolded help, establishment of intersubjectivity, and use of private speech. (1999 : 245).

This study concludes that the role of the L1 in the FL class, when all the students share the same first language, is crucial to access the L2 and to develop certain tasks successfully.

In this sense, their work ties in with that of Swain and Lapkin (1998) who also highlighted the potential benefits of L1 use in second language development. It should be pointed out, however, that while the focus of these studies was on the L1 use of students during collaborative writing tasks, the emphasis of the present research is essentially on the teacher's choice of language within a foreign language learning context. In such contexts, the three or four hours instruction received per week is often the only contact many of the students have with the foreign language. In this case, the issue is not so much on whether using the L1 during tasks can further students' cognitive and linguistic development, but rather whether or not the students have sufficient opportunity to actually hear and use the language they are in the process of learning.

In a later study by Macaro (2001), in which six student teachers' code switching practices in FL classrooms were analysed, very little L1 use was found. The reasons given by two of the trainees for using mainly the L2 in the classroom were mainly related to policy guidelines set out in the National Curriculum, the influence of the Communicative Language Teaching method, and to their own personal experience. In the case of one student teacher who considered the use of the L1 important on certain occasions, 
situations such as avoiding «breakdowns of the interaction» and «promoting a deeper understanding of semantic and syntactic equivalents» (2001: 544) were mentioned. The principal finding reached in the study is the fact that «students' use of the L2 was not brought about by higher measures of student teacher use of L2", which, as Macaro argues, supports the belief that «we are a long way from being able to claim that increased use of the TL leads to improved learning.» (2001: 545). In Macaro's opinion, no study, as yet, has been able to give evidence of a direct relationship between the absence of L1 use in the classroom and improved learning. As such, he suggests that a set of principles should be established to help guarantee an optimized use of both the L1 and the L2 in language classrooms.

Kim and Elder (2005), for their part, looked at the issue of the language choice made by teachers from different L1 backgrounds for instruction in their classes. The discourse of seven native speaker secondary school teachers, whose L1 was either Japanese, Korean or German, was audio-recorded and coded using an instrument known as the Functional Language Alternation Analysis of Teacher Talk. The range of TL use found in the discourse of these teachers ranged from between $23 \%$ and $88 \%$ while the L1 was used between $10 \%$ and $66 \%$ of the time, depending on the teacher. All the teachers were found to use the TL to a varying extent for the function of modelling, correcting or scaffolding learners' discourse. The results of this analysis showed that «TL use was not maximized either in quantity or quality in their lessons and therefore that the potential for intake and for meaningful communication on the part of the students was limited» (2005 : 377). The language choice of the teachers in this study was mostly influenced by previous teaching experiences.

In a more recent study, Kang (2008) questioned the advisability of implementing the policy of Teaching English through English (TETE) in elementary schools in Korea. An elementary class in a school in Seoul was observed and the classroom discourse audio recorded. The main finding to emerge from the analysis was that TETE was not being carried out by the teacher for reasons related to her lack of proficiency in English (L2) and her concern that children would be discouraged by exclusive use of the L2 during lessons. Having observed negative reactions in the children when using the L2, she was of the opinion that this would lead them to a complete loss of interest in the foreign language. The teacher's fear of not being understood was observed in her immediate L1 translations of utterances that, due to their simplicity, did not need the Korean equivalent for the students to understand them. The teacher claimed that she provided the students with translation because "however simple your TL inputs may seem to you, your students may feel confused about them. If I fail to supply LI translations right then and there, their interest will sag substantially and it will be pedagogically harmful to them.» (2008: 223). Important comparisons can be made, as we shall see, between the teacher in Kang's study and the Spanish EFL teacher in the present paper.

In a different educational context, specifically the teaching of Japanese as a foreign language in English secondary schools, Hobbs, Matsuo and Payne (2010) compared the use of the FL and the L1 by two NS and one NNS teacher of Japanese. Interestingly, they found that both NS of Japanese actually made much less use of the FL in the classroom than the NNS English speaking teacher, despite working within the same communicatively oriented environment. Japanese was used by both NS teachers only for introducing and practising new lesson content and in formulaic expressions for opening and closing 
lessons. The rationale behind the teachers' failure to use the FL stemmed from their concern that investing valuable classroom time in giving instructions and explanations in Japanese was unnecessary. The authors suggest that the teachers' preference for using the students' L1 in Japanese lessons may be strongly related to their past learning experiences and specific cultural background. They quote the words of a head teacher who had remarked that 'Japanese teachers in particular seem to have a hard time getting over a 'lecture-oriented' style' (55).

Given the conflicting evidence from the studies reviewed above, all of which have been carried out in a variety of different learning contexts and with teachers of different age groups, the present study attempts to provide further insight into the issue of language choice in the classroom by taking a more in depth look at one teacher's use of language and her justification for doing so. Drawing on earlier research carried out by Kim and Elder (2005), the present study addresses not only how a non native EFL teacher uses language in a secondary classroom in Spain, but also highlights why particular choices are made. Two research questions were posed:

1. What language types does an EFL teacher use and for what purposes in a Spanish EFL classroom at secondary level?

2. What are the reasons given by the teacher for her choice of language in the classroom?

\section{Methodology}

\subsection{Subjects}

Data for the study were collected in a state secondary school of a medium-sized town in south east Spain. The teacher who agreed to participate in the research was an experienced female teacher who had been working in the centre for eight years and who was, in her own opinion, highly proficient in English. The English class which participated in the research was a second year group of students, twenty eight in total, of whom 12 were boys and 16 girls. They were aged between 13 and 14 and had been learning English as a foreign language for over eight years. The students in this class received 3 hours of English instruction each week.

\subsection{Data collection}

Two classes of 55 minutes were observed and recorded by means of a digital recorder given to the teacher and placed on her desk. Notes on non-verbal communication were taken at the same time by the researcher. Qualitative data was also collected from the teacher by means of a 10 minute interview which was audio recorded a month and a half after the observational data were collected. In this semi-structured interview, questions were addressed to the teacher with the purpose of checking to what extent she was aware of her language use in this Year 2 class, and to identify, if possible, the motives behind her choice of language for certain pedagogical functions.

The lessons analyzed in this paper formed part of a more extensive observation carried out in the classroom and were characteristic of the teaching and learning context 
experienced by the students. At this moment in time, the teacher and students were working on a Unit from the text book Spotlight 2. The focus in both lessons was essentially on the revision of verb tenses. In the first of the lessons observed, the 28 students in class were divided into two groups of fourteen. Each group was taught separately by different teachers so that more attention could be paid to individuals by reducing the number of students per group. The goal of the first of the two lessons observed was to help the students understand the differences in use between the past simple and the past continuous. Their attention was focused on a written text (A Strange Experience) containing examples of the tenses. The students read the text individually and then listened to a recording, which the teacher paused after every sentence to ask for an L1 translation. The rest of the session was devoted to the revision of grammar for an upcoming test. Such tests are often a regular feature of many secondary school classrooms such as this one where teachers follow closely the contents and revision sections of EFL text books. Students also completed a vocabulary exercise on the topic of houses. The class was teacher-led, except for the individual reading activity. In the second lesson, the students corrected their homework as a teacher-whole class activity, translating English sentences into Spanish. The rest of the session was devoted to revision of the past simple and continuous tenses, with students completing written exercises on photocopied handouts.

\subsection{Data Analysis}

In order to analyse the data, two segments of 10 minutes each were extracted from both lessons for transcription and coding. In total, forty minutes of lesson time were analysed in an attempt to standardize the data for comparison purposes (Kim and Elder, 2005). The ten minute segments were considered to be representative of the activities taking place and offer an overview of the teacher's discourse and its different functions. The transcription conventions followed for data transcription were those established by Walsh (2006), in which language is not corrected and no conventions of punctuation are used.

Once transcribed, the teacher and students' speech was divided into AS-units following the definition and conventions used by Foster, Tonkyn and Wigglesworth (2000). The AS unit is a mainly syntactic unit defined as «a single speaker's utterance consisting of an independent clause, or sub-clausal unit, together with any subordinate clause(s) associated with either.» (2000: 365). The lesson transcripts were then coded using a systematic framework known as the Functional Language Alternation Analysis of Teacher Talk (FLATT), designed by Kim and Elder (2005), to analyse the pedagogic functions of teacher talk. Two of the three ${ }^{1}$ categories of this multiple category system were used to classify the data: i) the type of language used by the teacher and ii) the pedagogic function of the discourse. This first category includes five subcategories according to the degree of alternation of the TL (English) with L1 (Spanish), while the second category includes a typology of specific pedagogical functions. The transcripts,

\footnotetext{
1 The third category in Kim and Elder is "the goal of the interaction" (2005: 360).
} 
divided into A-S units, were colour coded using the 'language use' category of the FLATT. The colour coded transcripts were then further analysed to identify the pedagogic functions of the teacher's speech. Each A-S unit was assigned to a specific function which was labelled on the transcript. In order to improve reliability, two raters jointly coded the sessions, using the audio recordings to clarify any ambiguous utterances. In this way, problematic units were discussed until a decision was agreed upon. The functions and their definitions were adapted from those first reported by Kim and Elder (2005), although the specific examples provided below are from the data collected in this study.

\subsubsection{Pedagogical Functions of Teacher Talk}

Marker (Mar)

Utterances that indicate the beginning or end of a topic or move boundary. They usually appear as «bien», «vale», «ok», etc.

$\mathrm{T}$ os quiero también recordar que tenéis exámenes de otras materias y que tenéis que repasar y que estudiar vale? Bien

\{I want to remind you that you've also got exams in other subjects and that you have to revise and study, ok? All right $\}$

Starter (Sta)

A statement, a question or a command, generally occurring at the beginning of a lesson, that directs the attention of the students to the following elicit.

$\mathrm{T}$ ¿qué vamos a hacer? vamos a empezar

\{What are we going to do? We're going to start\}

Display Question (Dqu)

A question to which the teacher expects a specific answer and that is asked with the intention of checking the linguistic knowledge of the student.

$\mathrm{T}$ se supone que paran en un restaurante y nos van a describir el restaurante ¿cómo era el restaurante?

\{we imagine that they stop at a restaurant and that they're going to describe the restaurant. What was the restaurant like?\}

Truncation (Tru)

A truncated statement or question with a rising intonation that requires the students to complete the truncated part.

$\mathrm{T} \quad \mathrm{y}$ de qué época eran?

\{What period were they from?\}

L pasados

\{the past\}

T pasados de otro...

$\{$ the past, from another...\}

Check (Che)

Questions enabling the teacher to assess the progress of the lesson and to check if there are any comprehension problems. They can appear as «¿verdad?», «¿de acuerdo?» 
$\mathrm{T} \quad$ venga ¿todo el mundo ha acabado con la lectura?

\{Has everybody finished reading yet?\}

Directive (Dir)

A command in its unmarked form which requests an action (linguistic or non-linguistic) from the students that is physically possible at the time of the utterance. Phrases typically include stating a word or phrase for students to translate.

$\mathrm{T}$ vamos a escuchar las preguntas y las vamos a ir intentando responder pero en voz alta

\{We're going to listen to the questions and we're going to try to answer them but out loud\}

Prompt (Pro)

Utterances used to encourage the students to accomplish a directive by reinforcing it. They usually appear as «venga» «vamos», «rápidamente».

$\mathrm{T}$ sí, lo vamos a traducir, vamos a leer el texto para empezar, venga \{yes, we're going to translate it, we're going to read the text first, come on

Pointer (Poi)

Page or task numbers, or words/phrases indicating a specific point in a text book activity or text.

$\mathrm{T}$ vamos a empezar entonces con la lectura. The title is 'A Strange Experience' ¿vale?

\{We're going to start reading. The title is 'A Strange Experience' ok?\}

Accept (Acc)

The repetition of a student's reply or a phrase that indicates that the teacher has heard a response and has noted that it was appropriate.

L una extraña experiencia

\{a strange experience

$\mathrm{T}$ vale, una experiencia extraña, una extraña experiencia

\{ok, a strange experience, a strange experience $\}$

Evaluate (Eva)

A statement or phrase which indicates whether a student's answer was correct or not.

L a Irlanda

T a Irlanda very good

\{to Ireland, very good\}

Metastatement (Met)

A statement that refers to the organization of immediate or future classroom events and which help students understand the development of the lesson and the purpose of the activities.

$\mathrm{T} \quad$ venga en voz baja mientras yo voy a ir preparando el cassette... porque también lo vamos a escuchar 
Marisa Morata, Yvette Coule $\quad$ Teaching English Through Spanish: A secondary School EFL...

\{come on, quietly, while I start getting the cassette ready... because we're going to listen to it as well $\}$

\section{Model/Correct/Scaffold (MCS)}

The acts in this category help students learn new language models, grammatical structures or pronunciation in the TL. Since they frequently occur simultaneously, these teaching acts are grouped into one category. They can consist of any sentence form or fragment, including the teacher's provision of answers when the students are unable to respond,

$\mathrm{T}$ recordad siempre que el pasado continuo, que os recuerdo que es lo que entra para el examen, siempre indica un proceso ¿verdad?

\{always remember that the past continuous, which I remind you will be in exam, always indicates a process, ok?

\section{Discipline (Dis)}

Any statement or naming of a student with the intention of changing non-acceptable behaviour in order to maintain attention.

$\mathrm{T}$ Pablo, para poder desarrollar la clase de forma normal te voy a pedir que me des la muleta

\{Pablo, I want to get on with the class as normal so I'm going to ask you to give me your crutch please\}

\section{Results And Discussion}

\subsection{Summary of the language used by the teacher}

The teacher's use of language in both lessons is reported in terms of a) the amount of total teacher talk in comparison with student talk, b) the language types used and c) the choice of language type for different pedagogical functions.

a) The amount of total teacher talk in comparison with student talk

Table 1. Total amount of students talk vs teacher talk.

\begin{tabular}{|c|c|c|c|c|}
\cline { 2 - 5 } \multicolumn{1}{c|}{} & \multicolumn{2}{|c|}{ Student talk (in words) } & \multicolumn{2}{c|}{ Teacher talk (in words) } \\
\cline { 2 - 5 } \multicolumn{1}{c|}{} & $\mathrm{N}$ & $\%$ & $\mathrm{~N}$ & $\%$ \\
\hline Session 1 & 936 & $14 \%$ & 5970 & $86 \%$ \\
\hline Session 2 & 906 & $15 \%$ & 5190 & $85 \%$ \\
\hline
\end{tabular}

Table 1 presents the amount of teacher talk and student talk in both sessions as counted as percentages of the total number of words spoken by both. Although it is important not to over interpret these results as the word estimates are approximate, the results do indicate that the teacher dominates the classroom discourse in both sessions and to a very similar extent: $86 \%$ and $85 \%$ respectively while the students' interventions do not exceed $15 \%$. 
The total amount of teacher talk tells us very little other than that the class was evidently teacher centred and that opportunities for the students to contribute actively to the interaction were scarce. It is important, therefore, to look more closely at the teacher's choice of language, whether L1 or TL, and how it is used in relation to her pedagogical goals, in order to shed light on the quality of the linguistic environment. In an EFL context such as this, in which the teacher is the main source of TL input, it might be expected that optimal use will be made of the TL in class to create conditions conducive to language learning.

\section{b) Language types used by the teacher}

The percentages for the teacher's choice of language types in both sessions are presented below. In both sessions, an almost exclusive use of the L1 is observed, increasing from $68 \%$ to $84 \%$ in Session 2. These percentages are high, in comparison with the study by Duff and Polio (1990), in which similar L1 use was found in only two of the thirteen teachers' speech. The two teachers reported by Duff and Polio (1990) used the L1 in class for $69 \%$ and $90 \%$ of the time, figures which are close to the ones reported here. In the study by Kim and Elder (2005), the highest percentages of L1 use correspond to two Korean L1 teachers who used their L1 63\% and $66 \%$ respectively. Both these percentages are still lower than those identified in the Spanish teacher's discourse.

Table 2. Teacher's Language Use in Session 1.

\begin{tabular}{|c|c|c|c|c|c|c|c|c|c|c|c|}
\cline { 2 - 11 } \multicolumn{1}{c|}{} & \multicolumn{2}{c|}{ L1 } & \multicolumn{2}{c|}{ L1c } & \multicolumn{2}{c|}{ Mix } & \multicolumn{2}{c|}{ TLc } & \multicolumn{2}{c|}{ TL } & Total \\
\cline { 2 - 12 } \multicolumn{1}{c|}{} & $\mathrm{N}$ & $\%$ & $\mathrm{~N}$ & $\%$ & $\mathrm{~N}$ & $\%$ & $\mathrm{~N}$ & $\%$ & $\mathrm{~N}$ & $\%$ & 284 \\
\hline Teacher & 194 & $68 \%$ & 11 & $4 \%$ & 29 & $10 \%$ & 6 & $2 \%$ & 44 & $16 \%$ & \\
\hline
\end{tabular}

Table 3. Teacher's Language Use in Session 2.

\begin{tabular}{|c|c|c|c|c|c|c|c|c|c|c|c|}
\cline { 2 - 12 } \multicolumn{1}{c|}{} & \multicolumn{2}{c|}{ L1 } & \multicolumn{2}{c|}{ L1c } & \multicolumn{2}{c|}{ Mix } & \multicolumn{2}{c|}{ TLc } & \multicolumn{2}{|c|}{ TL } & Total \\
\cline { 2 - 11 } & $\mathrm{N}$ & $\%$ & $\mathrm{~N}$ & $\%$ & $\mathrm{~N}$ & $\%$ & $\mathrm{~N}$ & $\%$ & $\mathrm{~N}$ & $\%$ & \multirow{2}{*}{247} \\
\hline Teacher & 207 & $84 \%$ & 8 & $3 \%$ & 12 & $5 \%$ & 1 & $0.5 \%$ & 19 & $7.5 \%$ & \\
\hline
\end{tabular}

c) Use of the L1

The L1 is by far the most frequent language type used by the teacher and for a variety of different purposes. L1 use is observed when giving students task instructions, for metalinguistic and metacognitive explanations, to refer to future classroom events, for dealing with inappropriate behaviour and for praising students. It might be argued that the L1 as the language choice of the teacher is depriving the learners of vital organizational and linguistic input that could help to develop their L2 comprehension. Polio and Duff 
(1994), for example, see L1 use as the missing of a useful opportunity «to process communicative TL input, to practice new TL structures thoroughly in non mechanical ways, and also to express and resolve comprehension problems in the TL» (1994: 322). However, the reasons given by the teacher for this language choice are founded on her belief that she was helping the students feel more confident by ensuring they understood everything that was said in class. In her interview, she claimed that they felt lost when she spoke in English and that by using the L1 the students felt more in control of the situation. This reasoning coincides partially with results reported by Macaro (2001) whose student teachers' used the L1 for two main functions: giving procedural instructions for activities, and controlling students' behaviour. The following excerpts from the teacher's speech in both sessions illustrate her reliance on the students' mother tongue for organizational input (excerpts 1), classroom management (excerpt 2), praising (excerpt 3) and metacognitive explanations (excerpt 4).

T Vamos a escuchar las preguntas y las vamos a ir intentando responder pero en voz alta. \{We're going to listen to the questions and we're going to answer them out loud\}

T Te estoy pidiendo de forma educada que guardes silencio y sigas la clase, ¿vale? \{I'm asking you politely to be quiet and to follow the class\}

$T \quad$ Perfecto. $\{$ Perfect $\}$

T Siempre que hagamos una lectura tenemos que pensar que el título nos va a dirigir, ¿verdad? va a hacer que tengamos unas expectativas de la lectura ya sabiendo el título pues sabemos qué podemos esperar ¿verdad? y se van a activar en nuestra cabecita pues una serie de ideas que ya tenemos ahi acerca de lo que podemos esperar de un texto de misterio \{Every time we read we have to think that the title can help us, ok? It will give us some expectations about the reading text. If we know the title then we know what to expect, right? And this will set us thinking about what we might expect from a mystery text

d) Use of the $T L$

Consequently, and as can be seen in Tables 2 and 3, the amount of target language (TL) use in this classroom is very low. Only $7.5 \%$ to $16 \%$ of the teacher's utterances are produced in the L2. Although less frequently than with the L1, the teacher occasionally uses the TL to elicit responses from the students to display questions or produces TL utterances which act as prompts for the students to translate. Finally, the TL is also used to correct students' incorrect responses, with the teacher's TL corrections appearing as a repetition or reformulation of the student's utterance.

\section{T Who was David on holiday with? \\ L4 In Ireland.}




That were the people in the restaurant doing?
L2 Qué personas del restaurante... \{People in the restuarant...\}
$L \quad$ He was sitting in the chair.
$T \quad$ He was sitting on the chair.

In the first two examples above, the students' lack of comprehension is apparent even with simple TL utterances. This may be just one of the consequences that the absence of TL input in EFL classrooms can involve, since for many students the classroom is usually the only context which affords them opportunities to hear English. As Kim and Elder claim, «the FL teacher is often the only source of TL input and it is therefore taken for granted that teacher code-switching practice should be minimized since it has the effect of depriving learners of opportunities for TL intake and for 'authentic' communication in the TL» (2005: 356).

\section{e) Use of Mixed LanguageTypes: Codeswitching}

The use of codeswitching by the teacher ranges from $5 \%$ to $10 \%$ in both sessions. Switching from one language to another mainly occurs when the teacher provides the students with an immediate L1 translation of a TL utterance.

$T \quad$ So, please, go to page fifty-nine, página cincuenta y nueve, ¿vale?

T So, what do you think the text is going to talk about? ¿De qué creéis que va el texto?

Code-switching is also reported by Kang (2008:221), whose teacher provided the children with L1 translations of TL input since they «were thought to render the inputs more salient and easier to process». The teacher in Kang's study shows a concern with her pupils' interest and motivation arguing that «it would be kept high by providing them the L1 equivalents immediately after the TL sentences complicated in terms of syntax and vocabulary.» (2008: 222).

Although code-switching is a common practice among bilinguals, it does not seem to have a clear pedagogical purpose in the classroom. Since the students are aware that they will be provided with an immediate L1 translation of most TL input, they may quickly realize that there is little need to make an effort to understand the teacher's TL discourse. This could explain their comprehension difficulties when addressed directly in the L2 and possibly create a dependency on the teacher's code switch to confirm understanding. Wong Fillmore (1985) has argued that trying to work out what someone is saying is a crucial part of learning a language. In her opinion, translations 'short circuit' this process as students simply tend to ignore the original TL input. Given the teacher's concern with boosting the students' confidence in class, her code switching behaviour could in fact, have the opposite effect, since the lack of L2 input seems to have created a feeling of insecurity in the learners on the few occasions when the teacher does address them in the TL. 
f) Use of $\mathrm{LIC}$

L1c (citation) refers to language use in which a single TL word is embedded within an L1 utterance. The teacher's use of this language type is rare, not exceeding 4\%. L1c generally appears when the teacher provides students with an explanation of TL lexis, although there are also cases in which a TL word is inserted into an L1 utterance for no apparent reason. This latter use of both languages does not seem to have clear purpose nor present any apparent benefit for the students.

T 'So' es una... eh... es una palabrita nueva que vamos a ver hoy, que vamos a ver hoy, y so siempre lo vamos a utilizar para enlazar dos frases. ' $S o$ ' is a...eh...a new word that we're going to see today, and we're always going to use 'so' to link two phrases\}

T Dime tú una, María del Mar, please. \{You tell me one María del mar, please\}

g) Use of $T L c$

In the TLc language type, an L1 word is inserted within an TL utterance. This language type has an insignificant presence in the sessions analysed, ranging from $0.5 \%$ to $2 \%$. It appears only on a few occasions when a Spanish word either introduces or closes the TL utterance.

T I studied..., ¿vale? $\{\mathrm{ok} ?\}$

\subsection{Pedagogical Functions and Language Choice}

The following section reports on the most frequent pedagogical functions to appear in the teacher's discourse and the teacher's choice of language for each. The five most frequent pedagogical functions identified in the teacher's discourse appear in rank order in table 4. These five pedagogical functions are part of the fourteen identified in the sessions analysed. The functions most frequently used by the teacher include the Model/ Correct/Scaffold, Directive, Accept, Marker and Meta statement functions. The frequency and percentage with which each language type is used to express these particular functions is presented, as well as the total number of A-S Units produced per function. Similarities have been identified between these results and those of Kim \& Elder (2005). In their study, Directives and Model/Correct/Scaffold also appear among the top functions for most of the seven teachers they analysed. Accept and Markers also occur frequently, as in these sessions. 
Table 4. Summary of the Pedagogical Functions and Language types used by the teacher.

\begin{tabular}{|c|c|c|c|c|c|c|c|c|c|c|}
\hline & \multicolumn{2}{|c|}{ L1 } & \multicolumn{2}{|c|}{ L1c } & \multicolumn{2}{|c|}{ Mix } & \multicolumn{2}{|c|}{ TLe } & \multicolumn{2}{|c|}{ TL } \\
\hline & $\mathbf{N}$ & $\%$ & $\mathbf{N}$ & $\%$ & $\mathbf{N}$ & $\%$ & $\mathbf{N}$ & $\%$ & $\mathbf{N}$ & $\%$ \\
\hline $\begin{array}{l}\text { MCS } \\
(106)\end{array}$ & 59 & $56 \%$ & 11 & $10 \%$ & 21 & $20 \%$ & 3 & $3 \%$ & 12 & $11 \%$ \\
\hline $\begin{array}{l}\text { Dir } \\
(83)\end{array}$ & 59 & $71 \%$ & 3 & $4 \%$ & 8 & $10 \%$ & 1 & $1 \%$ & 12 & $14 \%$ \\
\hline $\begin{array}{l}\text { Acc } \\
(67)\end{array}$ & 49 & $73 \%$ & 1 & $1.5 \%$ & 5 & $7.5 \%$ & 2 & $3 \%$ & 10 & $15 \%$ \\
\hline $\begin{array}{l}\text { Mar } \\
\text { (56) }\end{array}$ & 53 & $95 \%$ & 0 & $0 \%$ & 0 & $0 \%$ & 0 & $0 \%$ & 3 & $5 \%$ \\
\hline $\begin{array}{l}\text { Met } \\
\text { (44) }\end{array}$ & 41 & $93 \%$ & 0 & $0 \%$ & 3 & $7 \%$ & 0 & $0 \%$ & 0 & $0 \%$ \\
\hline
\end{tabular}

This information is reflected graphically in Figure 1 which offers a comparison of the most frequently occurring functions and the language type used. It is clear that for all the functions the L1 is used more extensively than any other language type.

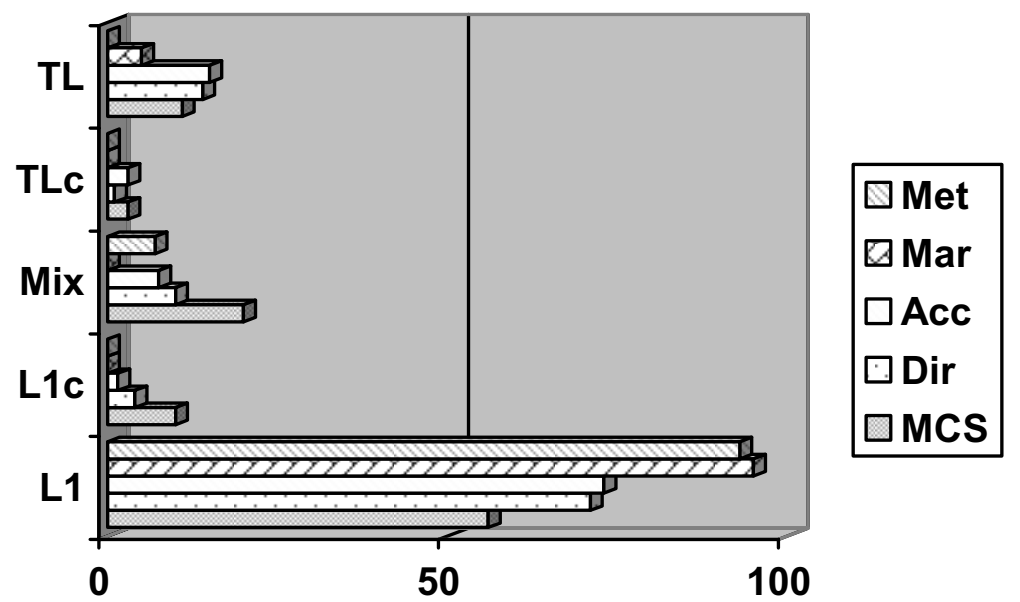

Figure 1. Most frequently occurring pedagogical functions and language types.

\section{a) Model/Correct/Scaffold}

The model/correct/scaffold function occurs mainly in the L1 (56\%). This is surprising considering that the purpose of this pedagogical function is precisely to provide students with rich linguistic input that they can understand and use for acquisition, and to provide feedback on their language use. $20 \%$ of the time it appears as a code switch, which is 
due to the teacher's reliance on L1 translations following many TL utterances. The TL is only used for this function for $11 \%$ of the total utterances of this kind. In contrast, Kim and Elder (2005) found that the model/correct/scaffold function was produced predominantly in the TL by all the teachers whose discourse was analysed.

\section{b) Directive}

Directives in the L1 correspond to $71 \%$ of the teacher's speech. Once again, this is surprising, since precisely because this function often requires a linguistic response from the students, we might also expect the TL to be used to elicit corresponding TL responses. However, directives given in the TL correspond to only $14 \%$ of the total units for this particular function. TL use has been identified mainly when the teacher provided the students with a L2 sentence to translate. Code switching is also used for giving Directives, occurring on $10 \%$ of all the occasions identified, often when the teacher failed to allow enough wait time to obtain a response from the students and so provided them with an L1 equivalent of the original utterance.

\section{c) Accept}

The accept function used by the teacher to let the students know that their replies were appropriate occurs $73 \%$ of the time in the L1 and $15 \%$ in the TL. This function appears usually as a repetition of the students' preceding utterance which, since they are mainly produced in the L1, so too are the teacher's repetitions. Acceptance words such as «vale», «efectivamente», etc, are a clear example of how the teacher could easily produce the same utterance in the TL, since the students would evidently have no problem in understanding the English equivalent of such simple words. In an attempt to introduce more TL in the EFL classroom, the teacher could start by changing the predominance of the L1 for the most basic functions, such as this one.

\section{e) Marker}

The Marker function shows the highest percentage of L1 use, corresponding to $95 \%$. Markers consist of very short utterances, usually just one word such as «bien» or «vale» . They are used only 5\% of the time in the TL, which means that in the sessions analysed only three utterances of this type were produced in English. This is a further example in which the high percentage of L1 use could easily be changed to the TL, since the students are not likely to experience comprehension difficulties with these simple utterances.

\section{f) Meta statement}

The Meta statement function, which is used to talk about the organization and structure of the classes, appears $93 \%$ of the time in the L1. Since the aim of this function is to help the students understand the development of the lesson, it is not surprising that the L1 is the language type used, given the teacher's concern with ensuring the students' comprehension. The remaining meta statements occur as code switching, as the teacher regularly inserted TL words into her L1 explanations. 
Having analysed the teacher's most common pedagogical functions and her choice of language for each of them, the main conclusion to be reached is the teacher's reliance on the L1 as the main language of communication in this EFL classroom. The TL appears only rarely when directing the students to translate a written text, or to request a simple action - mostly linguistic - from them. Furthermore, in a significant number of cases, the TL utterances appear followed by a translation into the L1. In the following section, an attempt is made to understand the decisions or beliefs underlying the teacher's choice of language in the classroom as the results from the semi structured interview are now described.

\subsection{Interview with the Teacher}

The teacher's comments on her own language use provide us with insights into how she conceived her role in facilitating the students' language development, and how she justified her choice of language in this particular context. As in the interview held with the teachers in the study by Duff and Polio (1990), this Spanish teacher also showed a lack of awareness as regards her use of language. When asked which language she used mostly in class and why, the teacher answered «Spanish because if I speak English my students don't understand». She claimed that she could not allow herself to give explanations in English, since the students would get «completely lost». She also added that the exclusive use of TL only worked for very simple and controlled activities and with the help of the blackboard. However, when asked whether the students could understand her when she spoke in English, she answered «Some of them. Most of them, if they are paying attention», which is surprising, considering that she justified her use of Spanish by worrying about their lack of comprehension.

This concern with comprehension difficulties coincides with Kang (2008) whose Korean teacher claimed that due to the low level of English proficiency of the children, she preferred the exclusive use of Korean (L1) on occasions in which comprehension might have been difficult. It is important to remember, however, that in the case of Kang, the students were elementary school children, whereas the students in this study were teenagers who had been learning English for at least eight years. This leaves us wondering as to whether their lack of comprehension might be justified by the kind of learning experiences these pupils had experienced previously, or whether, in fact, the class teacher's low expectations of her pupils were accurate or not.

The interview data also reveals a lack of awareness from the teacher about her use of translations and code switching. The reasons she gave for doing so were related to her worry that any new vocabulary or language structures introduced without an L1 translation, would lead students to feel insecure and unable to follow the class. However, in the analysis of the lesson transcripts, constant L1 translations can be observed, even when dealing with very simple sentences, nor were new structures or vocabulary introduced in the lessons observed, as they focused mainly on revision for an upcoming test. As regards L1 translations, the teacher considered them «good for students». In her opinion, the more ways students have to perceive an utterance, the better they will understand it in the end. "There are several ways of presenting things, so they will get the meaning from some of them, for sure.» A general lack of awareness was also observed when she 
was asked what she used the L1 for. To this question, she answered "grammar», as if this was the only case in which the L1 appeared in her speech. Finally, the teacher also stated that she considered the development of communicative competence in her students as very important, although she agreed that opportunities for them to develop this competence in the classroom were scarce. Whether or not any of the students engaged in independent language learning activities outside the classroom remains beyond the scope of this study.

\section{Conclusions}

The findings from this study describe an EFL teacher's language behaviour in a classroom in a state secondary school in Spain and the reasons given by the teacher to support her language choices in this English class. Without denying the linguistic and cognitive advantages that L1 use can bring to language learners for certain tasks such as writing or meta linguistic reflection, and without wishing to delve deeply into a theoretical debate about the role of the mother tongue in language learning, it is perhaps surprising that this teacher relies so heavily on the L1 with students who, after eight years of language learning, should almost certainly be capable of understanding input given in the TL. Perhaps the answer lies in the teacher's intention, not explicitly stated but apparent in her language use, of concentrating on developing her students' knowledge of English grammar and vocabulary, rather than on helping them to communicate in English. If this is the case, then little has changed it would seem, in the twenty years since Duff and Polio (1990) first drew our attention to teachers' choice of language types in the classroom. Although the results obtained in this small case study cannot be directly extrapolated to other classrooms and contexts, it is not unreasonable to assume that the kind of discourse described here may also prevail in many other FL classes, particularly in formal learning environments such as secondary schools. In fact, if recent research is anything to go by, this teacher is not alone in her teaching style and use of language. It would appear that teachers from all over the world, of different nationalities and with different age groups, still rely on their mother tongue as the main language of communication in the classroom.

In this respect, several implications emerge from this research which could contribute to establishing a set of principles, as suggested by Macaro (2001), for optimal use of the L2 in classrooms. Primarily, we argue that where there is a need to increase the amount of L2 exposure in the classroom, as in many foreign language learning contexts, a starting point could be to help teachers to use the L2 specifically for those pedagogical functions which occur most frequently in their speech, including the modelling of new language and scaffolding of students' language use, correcting errors, giving directives, marking the beginning, ends and transitions between activities, accepting students' responses, etc. This does not necessarily mean having to give up all use of the L1 in the classroom; rather it is a question of understanding when L1 use might work in favour of learners' language development and when it might work against it.

In this direction, Moser, Harris and Carle (2011), have argued that specific training in improving teacher-talk is essential for those who teach in communicative classrooms. 
They describe a teacher-talk training course carried out with Japanese primary school teachers of English, in which the participants learned to improve their discursive strategies by recording, transcribing and analysing their own language output during communicative task-based activities. Significantly, the training course was important in raising the teachers' awareness of the relationship between their use of language and opportunities they created for learning. The implementation of courses such as this one, both for trainees and in-service language teachers, would certainly encourage teachers to reconsider how they might plan for more effective language use during lessons.

Similarly, as suggested by Hobbs et al (2010), emphasis in teacher education should be also be placed on the critical analysis of teachers' personal beliefs and the effects these have on their classroom practice. It is not an easy task for teachers who have themselves experienced traditional teacher-led classes, to be expected to carry out more student-centred, interactive teaching in the foreign language without an in-depth examination of their own philosophies of teaching and learning and how they influence their classroom practice. Active reflection and discussion of key issues may help teachers to alter their perspective or understanding of certain practices. Given, for example, that creating a safe and comfortable learning environment figures as a priority for many teachers, and that for some, like the teacher in this study, using the L2 may appear to threaten the security of the language classroom, it would seem important to help teachers to accept, as a basic premise, that not every word or sentence uttered in the L2 needs to be fully understood by students in order to follow a class successfully. Furthermore, by helping the students themselves to understand this, teachers would be taking the first step to increasing their confidence in understanding and using the foreign language. On the contrary, over protecting students by teaching a foreign language almost entirely through the medium of the first language, however well intentioned, is likely to do little towards fostering the development of their oral communicative competence.

It has also been pointed out that the degree of autonomy experienced by teachers in the classroom can be limited by constraining factors such as having to adhere to imposed schemes of work, formal exam preparation and parental pressure or by requirements to follow commercially produced text books (Benson, 2010). All of these constraints not only determine what teachers do in the classroom but also what they say and how they say it. It is often the case that in many classrooms in Spain, text book grammar-based activities take precedence over active oral participation from students. As Benson (2010) claims, however, teachers can 'create spaces for autonomy' (273) by innovating and experimenting within these constraints. Specifically within the context described in this study, we suggest that by making classes student-led rather than text book-led, by articulating more collaborative and motivating tasks and by raising her expectations of what the learners are capable of achieving, this teacher would almost certainly be able to increase the amount of oral interaction in the FL from all the participants in the classroom, including herself.

It is hoped that this snapshot of one teacher's language use will help both practitioners and teacher trainers to reflect on the ways in which the quantity and quality of foreign language input can be made more available for learners. Further research is necessary to build on these conclusions. 


\section{Glossary}

Code switching: The alternation between two languages during conversation.

Communicative Competence: The ability to use language effectively for communication.

Discourse: A unit of language greater than a sentence.

EFL: English as a foreign language

ESL: English as a second language

FL: A foreign language which is not normally used for communication in a particular society. English is a foreign language in Spain and Spanish is a foreign language in England

Formulaic speech: Phrases and expressions learned as wholes or chunks.

L1: The mother tongue.

L2: A term used to refer to second languages or foreign languages.

Pedagogical Function: The language used by the teacher for specific purposes in the classroom. Common functions include asking questions, giving instructions or modelling new language.

SLA: Second Language Acquisition. The term is used to refer to research and theory related to the learning of second and foreign languages.

Target language: The language that the learner is attempting to learn.

Teacher talk: The adjustments made by teachers to both language form and language function in order to facilitate communication in the classroom.

\section{BibLiOgRAPHY}

Antón, M. \& Di Camilla, F. (1998), «Socio-Cognitive Functions of L1 Collaborative Interaction in the L2 Classroom», The Canadian Modern Language Review, 54, 3: 314-353.

Benson, P. (2010). 'Teacher education and teacher autonomy: Creating spaces for experimentation in secondary school English language teaching'. Language Teaching Research 14 (3): 259275.

Duff, P.A. \& Polio, C.G. (1990), «How Much Foreign Language Is There in the Foreign Language Classroom?» The Modern Language Journal, 74, 2: 154-166.

Ellis. R. (1994). The study of second language acquisition. Oxford: Oxford University Press

Hobbs, V., Matsuo, A., \& Payne, M. (2010) Code-switching in Japanese language classrooms: An exploratory investigation of native vs non-native speaker teacher practice'. Linguistics and Education, 21: 44-59

Kang, D.M. (2008), «The Classroom Language Use of a Korean Elementary School EFL teacher: Another Look at TETE», System 36: 214-226.

Kim, S. \& Elder, C. (2005), «Language Choices and Pedagogic Functions in the Foreign Language Classroom: a Cross-linguistic Functional Analysis of Teacher Talk», Language Teaching Research, 9, 4: 355-380.

Krashen, S.(1985) The input hypothesis. London: Longman

Long, M. (1985) 'Input and second language acquisition theory'. In Gass, S \& Madden, C. (Eds) Input in second language acquisition. Rowley. Mass: Newbury House, 377-93 
Macaro, E. (2001), «Analysing Student Teachers' Codeswitching in Foreign Language Classrooms: Theories and Decision Making», The Modern Language Journal, 85, 4: 531-548.

Moser, J, Harris, J \& Carle, J. (2011) 'Improving teacher talk through a task based approach' ELT Journal. Advanced Access published April, 15. Accessed on $18^{\text {th }}$ May 2011.

Polio, C.G. \& Duff, P.A. (1994), «Teachers' Language Use in University Foreign Language Classrooms: A Qualitative Analysis of English and Target Language Alternation», The Modern Language Journal, 78, 3: 313-326.

Swain, M. (1995). Three functions of output in second language learning. In G. Cook \& B. Seidelhofer (Eds). Principles and practice in applied linguistics Oxford: Oxford University Press, 125-144.

Swain, M and Lapkin, S. (1998). Interaction and second language learning: Two adolescent French immersion students working together. Modern Language Journal 82. 3: 320-337.

Tonkyn, F.P. \& Wigglesworth, G. (2000), «Measuring Spoken Language: A Unit for All Reasons», Applied Linguistics, 21,3: 354-375.

Walsh, S., 2006. Investigating classroom discourse. London: Routledge 